DOI: http://doi.org/10.22364/ruslat.glp.08

\title{
Оксана Пашко
}

\section{Студент-филолог в Советской Украине 1920-х гг. (на материале записных книжек Соломона Рейсера)}

В статье анализируются неопубликованные записные книжки Соломона Абрамовича Рейсера (1905-1989), которые хранятся в киевском архиве Института митературы им. Т. Шевченко НАН Украины (Киев). В работе показано, что такие эго-Аокументы могут стать важным источником Амя изучения митературной и культурной ситуации в Киеве 1920-х гг. Также на основе архивных документов идентифицируется кичность близкой знакомой С. Рейсера, Анны Николаевны Оберучевой (1891-1982), участницы одного из первых громких политических процессов в СССР - Киевского областного Центра Аействия (1923-1924), своячницы культуролога и историка Николая Павловича Анциферова.

Ключевые слова: Соломон Абрамович Рейсер, Николай Павлович Анциферов, Анна Николаевна Оберучева, Татьяна Николаевна Оберучева, Илья Эренбург, Андрей Белый, Аневник, эго-документ, 1920-е годы, Киевский областной Центр Аействия

1920-е годы - переломные годы в истории, время формирования нового советского человека, периоА политических, социальных и культурных экспериментов. Этот периоА Аовольно поАробно воспроизводится в разАичного рода эго-Аокументах, в частности в Аичных Аневниках молоАыХ АЮАей 1920-х годов. ОАнако Аневниковых записей мичного характера, описывающих жизнь молодого человека в Советской Украине 1920-х годов, мало. В этой статье речь пойдет о неопубликованных записных книжках Соломона Абрамовича Рейсера (1905-1989), в будущем известного текстолога и митературоведа, который в 1917-1926 гг. жим в Киеве. Эти Аокументы хранятся в архиве С.А. Рейсера в Институте митературы им. Тараса Шевченко НАН Украины (отАел рукописей) и Ао сих пор не привлекали внимание ученых. Граничные Ааты «киевского архива» С. Рейсера: начало 1920-х начало 1930-х годов. В статье исследуются записные книжки 1922-1926 гг. (ИА, ф. 243, А. 26, 34, 38, 39), когаа С. Рейсер бым студентом Высшего института народного образования им. Арагоманова (ВИНО), куда он поступим в 1921 году (ИА, ф. 243, А. 41, А. 1). Сформированные в несколько архивных дел записные книжки С. Рейсера - это около Аесятка блокнотов, общих тетрадей (на обложках которых характерные Аореволюционные виньетки), отдельные мисточки мелко исписанных записей. Некоторые из тетрадей имеют самодельную обложку, на которой фиксируются конечные 
Ааты записей и периодически указывается жанр записей: «Заметки, мысли, конспекты, выписки и пр.» (ИА, ф. 243, А. 34), «Записники. 1923-1926»

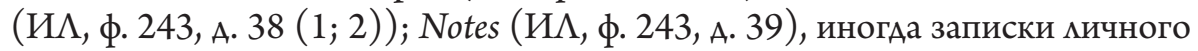
характера перемежаются конспектами прочитанной митературы: «ТетраАь

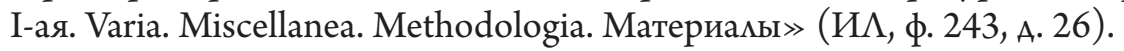

Стилистически переА нами разнородные заметки: описание событий, пересказ случайно подслушанных анекдотов, слухов, разговоров, записи песен - своего рода «литература факта» в Аухе 1920-х; также имеются конспекты прочитанных книг; пересказ мекций; иногАа приводятся рефлексии наА случившимся, есть мирические отступления; порой это обращение к себе с призывом изменить жизнь, своеобразное самовнушение; некоторые тетради имеют эпиграфы. В 1924 году Аневники становятся слержаннее, появАяются черты эзопового языка, некоторые отрывки пишутся по-английски или по-немецки.

Родился С. Рейсер в 1905 году в Пуще-Водице, поселке городского типа, месте дач киевмян, с августа 1917 года семья переезжает в Киев. С 1921 года он учится в Высшем институте народного образования Киева (так называемом ВИНО ${ }^{1}$, Ао советской реформы образования - Киевский университет $^{2}$ ). Записи были сАеланы С. Рейсером в возрасте от семнадцати мет Ао АваАцаТи ОАного Года.

Из мекционной книжки студента мы узнаем о прослушанных им Аисциплинах и успеваемости (в основном «уАовлетворительно» и «хорошо», только по истории Аревнерусской митературы, истории новой русской $и$ тературы и народной словесности - «отлично»). Тема кандидатской работы С.А. Рейсера формулировалась таким образом: «Из наблюдений наА русским стихом в связи с преподаванием поэтики в школе» (ИА, ф. 243, А. 41, ^. 4-6). В связи с непролетарским происхождением, С. Рейсер Аолжен был платить за свое обучение, поэтому первую половину Аня он работал. Служиц он в отАеле техотчетности Коммунального преАприятия государственного коммунального хозяйства, где познакомился с Анной Николаевной Оберучевой, помощником завеАующего поАотАела, ставшей оАной из важных героинь записок молодого студента.

Из записных книжек мы можем реконструировать образ автора - своеобразного молодого человека 1920-х гг., ироничного, иногАа циничного, в меру карьериста («ЗАоровый карьеризм в жизни необходим. Без него пропадешь ни за что» $(И \Lambda, ф .243$, А. $38(1), \Lambda .6))$, который и по воспитанию, и

1 Такой советский новояз, странного рода аббревиатуры, пародировались киевмянами: «Бывшее “ВИНО” называется теперь “КИНО”... от университета до КИНО “Аистанция огромного размера”» [перевод мой. - О. П.] (3.11.1924, Єфремов 1997: 158).

2 Реформа образования в Украине была направлена на сокращение в учебном процессе академической составмяющей и увеличение пеАагогической. 
по скиаду характера, и по случившимся с ним в этот период событиям воспринимает советскую вцасть как чужую.

Отметим, что в отличие от России, в Украине советское правительство окончательно утверАилось только в апреле 1920 года после многочисленных политических изменений, поэтому и воспринимацась часто как инородное тело. Молодой Рейсер солиАаризируется с Жорж Санд в скептическом отношении к Аемосу, цитируя ее высказывание о том, что во всеобщем избирательном праве «число господствует наА умом» (ИА, ф. 243, А. 38 (2),

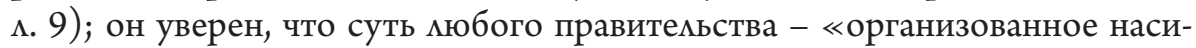

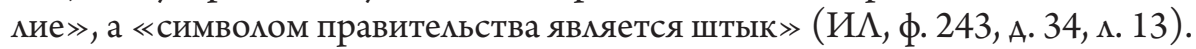
С. Рейсер констатирует у некоторых коммунистов болезнь «комчванство», иронизируя: «на каком сборе, то бишь < ...> съезде партии, принят Аогмат

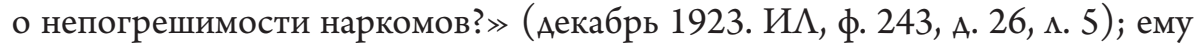
чужАы тексты-манифесты советской идеологии: «Аля меня всегАа были не понятны слова "Интернационала" "Никто не Ааст нам избавменья, ни Бог (понятно), ни царь (то же) и ни герой (?)”. Вот тут не понятно. Без геройства освобождения не будет» (Аекабрь 1923. ИА, ф. 243, А. 26, А. 13 об.).

На фоне популистских и агрессивных слоганов про борьбу, характерных Аля 1920-х годов, Рейсер считает борьбой шашки, шахматы, мыжи, теннис. Своими «боевыми Анями» он называет занятия и находит упоение в «боевой радости в области мичного усовершенствования» (ИА, ф. 243, А. 34,

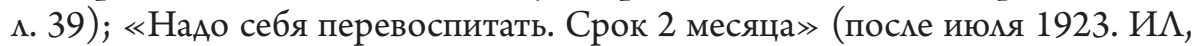

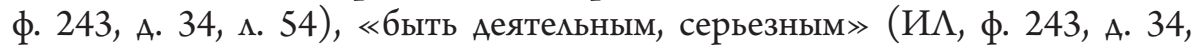
$\Lambda .55)$; говорит о важности «самоограничения», «не ругаться - слеАить за своим языком - это очень важно» (ИА, ф. 243, А. 39), «сделать себя заня-

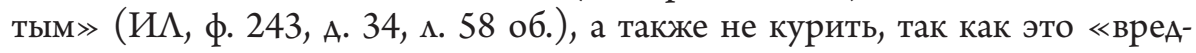
ная привычка», «вреАно отражающаяся на организме нервных субъектов (и я такой). Расслабцяет, отнимает много времени и денег» (9.08.1923. ИА, ф. 243, А. 38 (1), ^. 68). А. Рожков в книге «В кругу сверстников» описывает Аве «биографические стратегии» молодых мюдей 1920-х гг.: «мужики» (пролетарское происхожАение, общественная активность, намеренная грубость) и «жоржики» (непролетарское происхождение, намеренная воспитанность, сАержанность, аккуратность в одежАе) (Рожков 2016). С. Рейсер представляет в своих записных книжках желаемую Аля него вторую стратегию повеАения.

В плане милитаризации, службы в армии, С. Рейсер - не советский чемовек, на него угнетающе Аействует атмосфера военных учрежАений, казармы. Он мюбыми способами хочет избавиться от призыва в армию. Не разделяет он и митературные вкусы советской власти, категорически отрицая «пролетарскую поэзию», не понимая, по каким критериям ее вообще можно вылелить. Многочисленны свидетельства С. Рейсера о новом советском быте. Отличительным запахом нового быта является «канализационная вонь» («Что же Аелать, если оказывается, что мавровый венок Коммунальных ПреАприятий пахнет запахом сточных вод ОтАела Коммунальной 


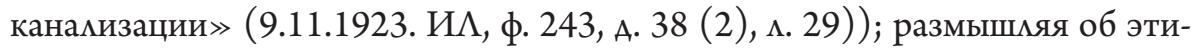
мологии ругательств, он отмечает распространение «порнографических картинок» $(6.10 .1923 . И \Lambda$, ф. 243, А. 38 (2), ^. 26), говорит о взятках и безработице. Эту корреляцию мотивов нечистот и советской власти встречаем и в Аневнике известного украинского митературовеАа и киевмянина Сергея Ефремова в 1924 году: он пересказывает слух о том, что в мавзолее прорвало канализационную трубу и залило помещение, причем это событие «воспевалось» в стихотворении и частушке, которые Ефремов цитирует: «Николай почим в Бозе, а наш Аенин - в навозе» (Єфремов 1997).

Упоминая о празАновании Октябрьской революции в 1923 году, Рейсер отмечает, что «особого подъема не было», он объясняет это тем, что «киассового сознания у народа, у массы нет, а национацьное есть в сильной степени» (ИА, ф. 243, А. 38 (2), ^. 30). Стихия анекАотов, слухи, которыми, «киевляне вознагражАают себя» (по М. Букгакову), своеобразное народное осмысление идей революции, которое можно было бы назвать «тихим сопротивлением» 1920-х годах, - тема отАельного исследования. Некоторые из анекдотов фиксируются Рейсером после посещений базара, записывается «подслушанное» в магазине, на умице, - эти моменты демают записки ценным источником по истории 1920-х. 24 января 1924 года, когда заговорили о смерти Аенина, С. Рейсер делает запись: «О Аенине уже бреАки. 1) Кто бым Аенин слышу я на Хрещатике? ЗАорово! 2) ГАе похоронят - не в императорском склепе $\Lambda и$ ? Еще кучше 3) Кто отпевать бу-

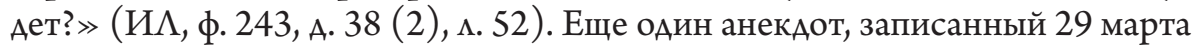
1924 г., обыгрывает советские мозунги, однако оценивается Рейсером как вульгарный: «Рассказывают, что утробные младенцы устроили митинг. Выставили по обсужАении ряА требований: 1) мало места - расширить жикую площадь, 2) темно - электрификацию, 3) не Аают свободы слова и 4) половых сношений. В общем, грубо» (ИА, ф. 243, А. 39, м. 26). Приведем еще несколько очень точных зарисовок киевского советского быта. 7 августа 1924 года С. Рейсер записывает: «Запрещены к продаже в кн<ижных> магазинах фимософы-идеалисты. Sic!» (ИА, ф. 243, А. 26, м. 22 об.). Аействительно, с приходом в Украину советская власть производила тотальную чистку книжных магазинов и библиотек с последующим запретом продажи определенных категорий митературы. Фиксируются в записках мелочи киевского церковного быта: «Аовкие, черт возьми, ребята. На витрине объявлений малой церкви Соф<ийского> Собора. 1) Храм - место Ауховного общения с Богом. 2) Хор - украшение храма. 3) Жертвуйте на хор и на

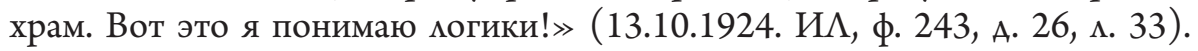

ИАеи 1920-х годов о важности гигиены близки С. Рейсеру и реконструируются из описания его распорядка Аня: «ФизотАел вполне хорошо. Сплю 8 часов. Утром и вечером гимнастика. Часто моюсь. Волос кручу мало. ЕАа нормально. Чувствую себя хорошо, холода не ощущаю... Совершенно нет. Характер. Трудно. Очень трудно изгнать эротомечтательность... Вообще я 


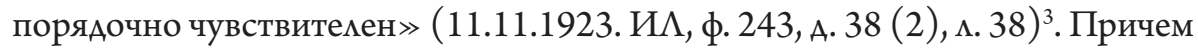
занятия спортом, гимнастикой студент скорее воспринимах не в контексте поАготовки своего тела к труАу и военной службе, как советские иАеологи 4 , а как что-то подобное чистому искусству викторианской эпохи, траАиции, восходящей к привычкам АенАи: «Спорт или физкультура. Принц Уэмьский $<\ldots>$ может Аелать, конечно, что ему угодно, но <...> молодежь, идущая в “спортклубы” в кавычках, Аолжна отАавать себе отчет, зачем идет она туда. ИАет ми она туда заниматься спортом. НЕТ! Этого ей не нужно. Чистый спорт=чистое искусство - нам сейчас не нужен» (5.05.1924. И А, ф. 243, А. 39, м. 36). Примечательно, что размышляя о роли спорта в жизни молоАого человека, он упоминает имя принца Уэльского, будущего ЭАуарда VII, который воспринимался как икона стимя 1920-х гг., преАставцяя собой типаж аристократа-спортсмена (Вайнштейн 2005: 561).

ОАнако не столько увлечение физкультурой Аелает молодого Рейсера похожим на молодого человека 1920-х годов ${ }^{5}$, сколько служба: как и большинство студентов того времени, он служил в конторе. ОАнако со службой, а особенно с «общественной работой», в записках связаны мотивы «омещанивания», «обмельчания», некоторой пошлости. Женщина, которая служит и занимается общественной работой, Аля молодого человека становится «общественницей» и «старой Аевой». Причем, если в мексиконе 1920-х годов «мещанство» связывацось со старомодностью, пошиостью, то Аля Рейсера именно слова «старомодный», «уютный» наполнены поможительными смыслами, тогда как «мещанство» - это знаки нового советского быта.

Несмотря на то, что Рейсер воспитывался в еврейской семье, у него в записках не отражается еврейский быт или кумьтура - ни на уровне речевом, ни тематическом, молодой человек ассоциирует себя исключительно с русской культурой. Исключения составляют размышления об антисемитизме, о Первой мировой войне и об обострившемся к середине 1920-х годов в СССР национальном вопросе. Он фиксирует анекдоты, например: нельзя говорить «поА-жидать трамвай», наАо говорить «под-евреивать

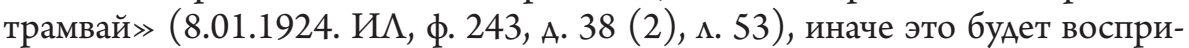
ниматься как антисемитизм. Анализируя причины антисемитизма, С. Рейсер вспоминает работу С. Аурье «Антисемитизм в Аревнем мире» (1922), с которой знакомился по рецензии в журнале «Анналы» (1923); по его

3 По сравнению с описанными А. Рожковым случаями нищеты, голода, неустроенности студентов 1920-х гг. (Рожков 2016), С. Рейсера вполне можно отнести к группе благополучных студентов.

4 Хоффманн пишет о советских концепциях физического труАа, важного «А^я поступательного Авижения на пути социального строительства» (Хоффманн 2018: $155)$, о том, что в СССР «часто не разделяли идеологическое зАоровье и физическое» (Хоффманн 2018: 169).

5 ОАнако А. Рожков считает, что «спорт... не стал в 1920-е годы массовым явлением в среде студентов» (Рожков 2016: 344). 
мнению, причина антисемитизма в том, что евреи «быстро осваиваются в новой атмосфере (их приспособляемость феноменальна), начинают себя чувствовать равноправными гражданами всюду (я русский)» (30.08.1923.

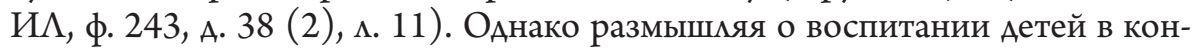
сервативной русской семье, он признает свою «чужАость» этим настроениям: «От этой вежливости православно-русской семьи, читающей “Новое время”, пьющей чай из самовара и идущей на войну, мне подчас Аелается как-то не по себе» (13(?).11.1923. ИА, ф. 243, А. 38 (2), ^. 33).

Отметим, что периоА киевской истории, зафиксированный Рейсером, явмяется периодом украинизации, когда преподавание в учебных заведения переводилось на украинский язык, а также все служащие Аолжны были саавать обязательный экзамен на знание языка. Этот же периоА - 1920-е годы - явцяется расцветом украинской кумьтуры и митературы, - то, что впоследствии получит название «расстрелянное возрожАение». Хотя С. Рейсер успешно освоиц украинский язык и митературу, он не мыслил себя как исследователь украинской митературы, в его студенческих работах находим только отдельные упоминания о творчестве Михайля Семенко и Павла Тычины, также в архиве имеется работа, посвященная сравнительному анализу творчества М. Семенко и И. Северянина. В мичных заметках появляются такие записи: «Теперь в связи с преобразованием ВИНО в ИНО, в связи с его пеАагогизацией и украинизацией “оставание” мое там просто абсурдность, и главное - потеря времени» (23.05.1924. ИА, ф. 243, А. 38 (1), м. 25). Характерная Аетаць: он вспоминает, как зайцем проникнул на знаменитую постановку Молодого театра известного украинского режиссера $\Lambda$ еся Курбаса, однако ни слова не пишет о самом Курбасе, упоминая только название пьесы - «Газ» Т. Кайзера; поражен он был скорее не режиссурой, а «моАностью и огромностью Аекоративного устройства»

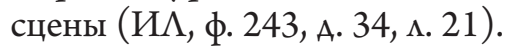

Характерно, что Рейсер принципиально не замечает «революционной» топонимики Киева, называя Пролетарский саА Царским. Вероятно, у него нет своего Киева, есть свой Петербург - в основном митературный, и когАа Киев совпадает с Петербургом - Петроградом - Аенинградом, он становится своим. Киевлянин Соломон Рейсер чувствует себя провинциалом. Собираясь в Москву, он записывает в Аневнике: «Только бы не быть в стомице Хлестаковым, или “гоголевским кузнецом”, попавшим в Петербург. Не Аелать УАивленные глаза, а “балетмейстеровать” $(19.10 .1923$. ИА, ф. 243, А. 38 (2), ^. 19 об.) (как можно догадаться, речь илет о гоголевском Вакуле).

В записках прочитывается еще оАин сюжет - проблема выбора будущей профессии: изучение митературы или поступление в Политехнический институт («теперешнее увлечение техникой очень симптоматично. Пришибленные революцией интемлигентики снова хотят кушать» (ИА, ф. 243,

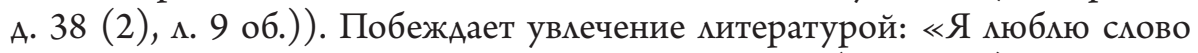
как таковое за то, что оно слово и больше не за что» $(1.11 .1923)$, «... грусть хватает мне сердце. Служи... учись в Политехникуме... брось филологию 


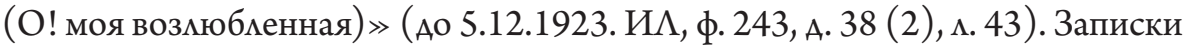
С. Рейсера - это записки инАивидуамиста, который не приемлет ничего колмективного; его путь к митературоведению - это не путь поэта или критика к научному изучению митературы, это путь ученого, преподавателя, который мечтает изучать митературу, сохранять свою индивидуальность и оставаться не включенным в современные события. «Но что сказать мне про

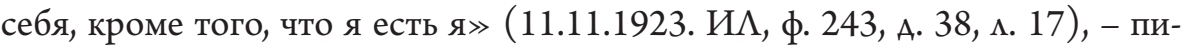
шет Рейсер, «Надо писать Я с большой буквы, как англичане» (ИА, ф. 243, А. 38 (2), ^. 11). Эта инАивидуацьность проявцяется в том, что он не хочет принимать участие в организации кружка «эсперанто» искмючительно «потому, что идее эсперанто не сочувствую, не вижу и не верю в его эфемерную сущность $\gg(И \Lambda, ф .243$, А. 38 (2), А. 20), хотя такое занятие и могло бы помочь ему в продвижении по служебной местнице. Соломон Рейсер начала 1920-х годов верит в способность мичности, а не комлектива преоАолеть все препятствия: «Гении не погибают. Тацанты тоже» (ИА, ф. 243, А. 38 (2), .47$)$, - уверен он.

В заметках прочитывается сюжет, который можно было бы назвать роман-воспитание, роман-карьера, Аовольно традиционная форма, характерная Аля романа XIX столетия. ОАна из центральных тем - карьера необходимость остаться на кафедре («я Аолжен все время иметь переА своими глазами выжженные в моем мозгу еАинственные Аля меня возмож-

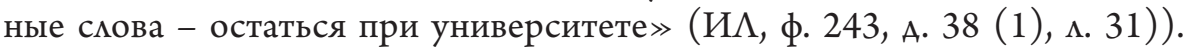
Постоянно встречаем на страницах и обращение к себе - о необходимости учиться, самосовершенствоваться. Возможно, тут уже проявмяются те особенности Аневника советского человека, которые Аж. Хелбек называет «воспитание Ауха», «борьбой за усовершенствование» (Hellbech 2009: 68-74), подробно описанные им на примере Аневников стахинской эпохи.

Аругая центрахьная тема записок Рейсера - поиск мюбимой женщины и размышиения о том, кто такие женщины, и каковы советские «барышни». Многие страницы записок посвящены мичности незаурядной женщине, в которую Рейсер бым влюблен или думац, что был влюбленным, - Анне Николаевне Оберучевой. Она была арестована в декабре 1923 года и приговорена в 1924 году к пяти годам мишения свободы условно из-за обвинения в участии в Киевском областном «Центре Аействия» (это был один из первых громких процессов против украинской и русской интемлигенции (1924), который проходик в Киеве). Украинский историк Наталья Васименко-Полонская, жена одного из главных обвиняемых - профессора права Николая Василенко, очень ярко описала выступление на суде Анны Оберучевой: «Анна Оберучева заявила, что стоит за демократию, за свободу слова и печати, что она против Аиктатуры и за полное равноправие. Она идеалистка и не может принять марксизма. Это говорила молодая девушка, курсистка, говорила четко и ясно. Она была больна и единственная из всех Аавала показания сидя, тихим спокойным голосом. Тысячеголовая толпа 
замерла и жадно мовила каждое ее слово, которые произвели большое впечатмение» (Полонська-Васименко 2011: 344) ${ }^{6}$.

Кем же была Анна Оберучева? Речь илет о свояченице Николая Анциферова, сестре его жены - Татьяны Оберучевой. Анна после смерти своей сестры и ареста Анциферова в 1929 году заменила его детям мать, а после второй мировой войны эмигрировала в США․ Аействительно, осужАенная в 1924 году, в 1929 году она уже могла выехать из Киева в $\Lambda$ енинграА. В протоколе Аопроса А. Н. Оберучевой от 25.10.23 привоАится анкета, гАе имеются слеАующие сведения: «Год рождения: 1891 г. ${ }^{8}$ из иворян г. Киева; Где учился: в Киевской женской гимназиия и Петербургском женском политехникуме ${ }^{10}$ и КИНХе ${ }^{11}$; Во времл войны: сестра милосерАия; Кто родители: отец б<ывший> полковник, умер и мать Екатерина

6 Перевод с украинского мой. - О. П.

7 В протоколе Аопроса Анны Оберучевой по Аелу Киевского областного Центра Аействия говорится, что ее отец - бывший полковник, а мать Екатерина Михайловна. Такое же имя матери семьи Оберучевых называет и Н. Анциферов. Это косвенное подтверждение того, что Анна Оберучева из записок С. Рейсера и Н. Анциферова - одно и то же кицо. Еще одно подтвержАение - аАрес проживания семьи: с 1909-1915 гг. в справочниках «Весь Киев» встречаем запись о том, что Оберучева Ек. Мих. проживает по М<алой>.-Вцадимирской, 37 (с 1913 г. - Столыпинская) именно этот аАрес называет Н. Анциферов; однако в справочнике 1916 г. указано, что Ек. Мих. Оберучева проживает уже по адресу Фундуклеевская, 52 (Календарь 1916: 182) - а вот этот аАрес фигурирует в следственном деле как место проживания обвиняемой.

8 В оАном из протоколов Аопроса ошибочно указано: гоА рожАения 1881 г. (ГА СБУ, А. 55435, т. 18, ^. 2), в Аругом протоколе говорится, что ей 32 года (ГА СБУ, А. 55435 , т. 18, ^. 13). Скорее всего, родилась Анна Оберучева в 1891 году.

9 Записки С. Рейсера позвомяют установить, что речь идет о Государственной гимназии Святой Ольги (Ольгинской гимназии) (ИА, ф. 243, А. 34, м. 33). В 1892-1914 гг. гимназия помещалась во фмигеле Первой киевской мужской гимназии. Про эту же гимназию пишет Н. Анциферов, вспоминая о киевской молодости: «Таня заканчивала министерскую гимназию, которая помещалась рядом с нашей 1-й. Я помню, как мы взбирались на стену нашего саАа и наблюАали гумяющих по своему саду гимназисток» (Анциферов 1992: 124).

10 В Аругом протоколе Аопроса уточняются биографические Аанные: «Я дочь полковника, училась в Петербурге на Высших женских политехнич<еских> курсах, которые окончить не успела, так как началась война 1914 года, и я добровольно поступила на курсы сестер милосердия, по окончании которых я поступила в армию и была на фронте до октября 1917 г. Вернувшись затем в Киев, я занималась уроками, некоторое время служила в Украинском Красном кресте, а в 1920 г. поступила в Управление Киевскими Коммунальными предприятиями, сначала на должность телефонистки и чертежника, гАе служу и сейчас, занимая с 1921 г. Аолжность помощника заведующего отделом технической отчетности, отАел этот ведает статистической отчетностью работы коммунальных преАприятий» (ГА СБУ, А. 55435, т. 18, м. 14).

11 Киевский институт народного хозяйства. 
Михайловна; Место службы в настоящее время: пом<ощник> зав<едующего> подотаела техотчетности Ком. ПреАпр. ГХ. Х.; Постоянное место жительства: г. Киев» (ГА СБУ, А. 55435, т. 18, м. 2); Адрес проживания: Фунаукиеевская, 52, кв. 17 (сегодня Уи. БогАана Хмельницкого). Из протокола допроса также следует, что Анна Оберучева была знакома с Натамьей Жекулиной (Евреиновой), женой поэта и журналиста Бориса Евреинова (1888-1933): « ... осенью 1921 года мне принес... Иван Сергеевич Павлюк записку на папиросной бумаге от Наталии Жекулиной, находящейся в Праге, с просьбой служить передаточным пунктом организации, ставящей своей целью сообщение за границу информации о положении Сов<етской> России. Зная Н. Жекулину и мюбя ее, я на это согласилась > (ГА СБУ, А. 55434, т. 18, ^. 2 об.). Оберучева раз десять передавала запе-

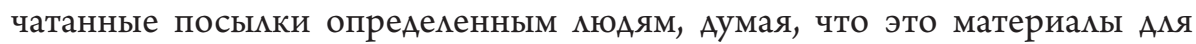
подготовки журнала. В своих показаниях в первом протоколе Аопроса она очень резко высказывается против советской власти: «А. Оберучева заявляет, что “советская вцасть Аолжна эволюционироваться..." Мое убеждение, что Коммунистическая партия сама придет к заключению о необходимости восстановления демократии. Вопр. Считаете ми Вы конспиративную Аеятельность актом враждебным соввласти? Отв. Аа, считаю ее актом враждебным. Вопр. Следовательно, вы являетесь врагом Советской вмасти? Отв. Аа» (ГА СБУ, А. 55434, т. 18, м. 2 об.). В тюрьме Анна Оберучева заболела, ее пытались забрать на поруки сотрудники учрежАения, в котором она работала (ГА СБУ, А. 55434, т. 18, ^. 15), оАнако им не позволили. ОАна из заключенных, участница процесса, Варвара Виноградова, в прошении следователю писала о состоянии зАоровья Оберучевой: Ава месяца пребывания в тюрьме отразились на ней «чрезвычайно тяжело», у нее порок серАца, слабые легкие и сильнейшее малокровие, «с ней почти ежеАневно бывают припаАки, сопровожАающиеся полной потерей сознания (явление анемии мозга) <...> появился крайне нехороший кашемь» (ГА СБУ, А. 55434, т. 18, м. 7-7 об.). Эти припаАки повторялись также во время суаа.

В записках «Из Аум о былом» Н. Анциферов создает очень выразительный портрет молодой Анны периода киевской жизни в Аоме «номер 37 : «молчаливая, замкнутая, со сАвинутыми бровями, она жила какой-то своей, неАоступной нам жизнью. Мы только замечали, как порой вспыхивали ее узкие глаза и что-то сильное, неукротимое просыпалось в ней. Она жила одной жизнью с нами, но как она ее преломляла в себе, никто из нас не знац. Мы называли ее “последовательницей Метерлинка”, ибо он учим молчанию» (Анциферов 1992: 123). Рейсер также оставим нам милые портретные зарисовки Анны Оберучевой, например, описав ее гардероб: «Анна Николаевна сегодня прелестна. Она пришла уже не в своем матроско-гомланаском костюме, а в черной юбке с белой старомодной блузкой. Блузка, вероятно, ее матери. Желтые чулки и такие же туфми дополнили ан-

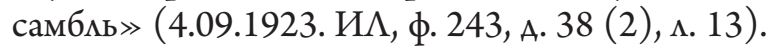


За месяц до ареста А. Оберучевой С. Рейсер посме отпуска был уволен со службы по сокращению штата (28 ноября 1923), спустя несколько месяцев он оказывается заинтересованным свидетелем политического процесса «Центра действия». С момента ареста А. Оберучевой его записные книжки кратко, но часто пестреют упоминаниями об арестованной. Ситуацию с советскими тюрьмами Рейсер преАставцял идеалистически, он описывает задумчивую женщину, которая одиноко стоит в камере и о чем-то Аумает. «My dear Anna. Love I you or not? Where know it? I don't know», спрашивает себя момодой человек после того, как побывал на суде, угадывается в этом сюжете что-то стендалевское, но наоборот, жертвой выступает женщина. Английский зАесь Аля того, чтобы потренироваться в языке, что свидетельствует скорее о наивности автора переА мицом трагических событий.

Размышияя наА собственной мюбовной историей, Соломон Рейсер много пишет о женщинах вообще. Он их оценивает очень консервативно, резко негативно относится к женской эмансипации, что находится в оппозиции к тенденциям женского Авижения 1920-х гг.: «Женщина, ставшая умной, теряет всякую женственность и приобретает мужественность» (после 19.10.1923. ИА, ф. 243, А. 38 (1), ^. 55). А.Н. Оберучеву он называет «интересной женщиной», по мнению Рейсера, женщине по природе свойственны «хитрость, скрытность, садистские наклонности» (ИА, ф. 243, А. 38 (1), м. 31-33). «Зачем женщины хотят быть мужественными. Разве им мало - быть женственными?» (ИА, ф. 243, А. 38 (1), А. 55), «рожАайте Аетей, варите пищу, шейте, читайте, если это и звучит старомодно» (ИА, ф. 243, А. 38 (1), м. 55). Он констатирует, что с революцией изменяется тип женщины, исчезают барышни. Но самые резкие высказывания встречаются у Рейсера по отношению к женщинам-«общественницам», которых он считает воплощением пошлости. Аюбопытно, что в киевской студенческой среде, в которой вращался Рейсер, был популярен 3. ФрейА: «ФрейА! О ты, ЗигмунА ФрейА, буАь милостив - истолкуй мой сон!» (7.06.1923. ИА, ф. 243, А. 38 (1), А. 34 об.) - молится советский студент, к тому же, он хочет подвергнуть психоанализу психологию современных советских Аевушек и ... шахматы.

Соломон Рейсер как человек, интересующийся митературой, периодически ходил на митературные вечера («Буду на Эренбурге. Видел Мандель-

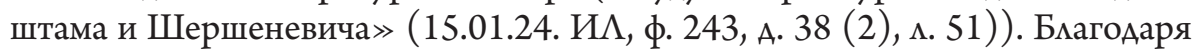
его увлеченности живым словом, имеем несколько уникальных отзывов о вечере Ильи Эренбурга и мекции Андрея Белого - обе состоялись в феврале 1924 г. В ранней юности Рейсер пережил большую увлеченность «Хулио Хуренито» Ильи Эренбурга, что потом не помешало ему считать этого писателя графоманом, наряду с Алексеем Толстым, Борисом Пильняком: «Если бы читатель читал, а не почитывал, не могли 6 существовать А.Н. Толстой, Пильняки и Эренбурги» (ИА, ф. 243, А. 38 (1), ^. 25). Эренбург, полагает Рейсер, А^я читатемей, «ААя которых чтение - это роА 
тюфячка, который они под себя подкмадывают, чтобы мягче бымо (сиречь не скучно), аналогично Пильняк. Мне это Ао крайности противно» (1924. ИА, ф. 243, А. 26, м. 19 об.).

Итак, 18 феврамя 1924 года Соломон Рейсер был на мекции И. Эренбурга; вот как он описывает свои впечатмения: «Эренбург типичный сопливый интемлигент, и сам буржуа ничуть не выше тех, на роль сатирика которых он претендует. Его митературность губит его... Речь его - рян мелких, а не метких, пошлых анекдотов, нагроможденных Аруг на Аруга. Если бы его докмаА сильно сократить, мог бы выйти толк» (ИА, ф. 243, А. 38 (2), м. 54). Из анонсов в киевских газетах можно преАположить, что речь скорее всего идет о мекции Эрнебурга «Пьяный оператор», посвященной современной Европе ([б.а.] 1924b: 4; [б.а.]. 1924c: 3).

Совершенно противоположно оценивает С. Рейсер мекции Анарея Белого (запись от 25 феврамя 1924 г.): «Бемый! Огромная величина. Гений! Он сумасшедший. Несомненно, или гениальный из гениальных актер. Он на меня произвел огромное впечатление. Как смел T. ${ }^{12}$ написать о нем поАобное. Он не смел написать так во всяком случае» (ИА, ф. 243, А. 38 (2), ^. 55). И чуть позже, 29 феврамя, он пишет: «Быть внутренне тактичным, воспитать в себе это, как говорит Белый (он на меня симьное, очень сильное впечатление произвел)» (ИА, ф. 243, А. 38 (2), ^. 55 об.). Киевская газета «Більшовик» анонсировала мекцию Андрея Белого «ОАна из обителей царства теней (о современной Германии)», которая состоялась 25 февраля в Пролетарском доме искусств ([б.а.] 1924а: 6). В записках молодого Рейсера мы имеем оАно из реАких свидетельств слушателей Эренбурга и АнАрея Белого в Киеве.

По-видимому, политический процесс «Центр Аействия», участницей которого стала Анна Оберучева, очень повлиял на самого Соломона Рейсера. Он замыкается, 5 января 1924 года пишет: «Стать еще более скрытным!» (ИА, ф. 243, А. 38 (2), м. 51). Изучая английский язык, С. Рейсер Аелает попытку вести Аневник на английском, возможно, чтобы зашифровать сообщение. ИногАа он пишет неопределенные местоимения: «те», «эти», - и зАесь уже очень сложно догаАаться о смысле сообщения. Эта осторожность молодого человека была обусловлена многими причинами. Следствие по Аелу «Центра Аействия» совпало со смертью Аенина, что также усугубимо напряженную обстановку в Киеве. Отметим, что уже через полгода (в октябре 1924 г.) после приговора обвиняемым (апрель 1924 г.) в Киеве начались «страшные аресты. Арестовано, говорят, около 700 человек» (28.09.1924. Єфремов 1997: 147). Также усилились меры по «чистке» среди студентов: «ВсюАу идет новая "чистка" - студентов, учитемей, скужащих. "Избиение ммаденцев тысячи"» (8.10.1924. Єфремов 1997: 150).

12 Скорее всего, имеется в виду высказывание $\Lambda$. Троцкого об Анарее Белом: «покойник, ни в каком духе он не воскреснет». 
К 1926 году на стилистическом уровне в записных книжках начинают прочитываться идеологические словечки современности: «статья по существу глубоко реакционна» (ИА, ф. 243, А. 39, ^. 16); «констатирую победу на фронте физическом» (ИА, ф. 243, А. 39, м. 37) - о роли самовоспитания; «типичная интемлигентская психология» (28 марта 1924, 243, 39: 24 об.). Появляются мысли о компромиссе с укрепмяющейся системой: «Что Вам комлективный Аоговор с ЦК КП заключить, что ми?» (конец 1923, после ареста А. Оберучевой; ИА, ф. 243, А. 38 (2), А. 40 об.), «В связи с полит <ической> проблемой надо что-то изменить в своем поведении» (ИА, ф. 243, А. 38 (2), 4). Судьба Анны Оберучевой и гибель самого близкого Аруга (он утонул) Аля Рейсера стали перемомными: он то впадает в Аепрессию, то восклицает: «Жить, жить, как хорошо жить» (15.04.1924;

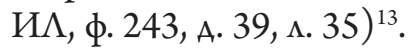

Подытоживая, можно сказать, что неопубликованные разрозненные черновые кичные записки Соломона Абрамовича Рейсера представмяют значительный интерес Аля изучения митературной ситуации в Киеве 1920-х годов - в статье преАпринята попытка обозначить наиболее весомые темы заметок. ПереА нами важный человеческий документ, в котором описывается внутренняя жизнь и взросление молодого мюбителя митературы и науки, волею судеб живущего в советском, чужом Амя него времени, и оказавшегосяся свидетелем важным исторических событий страны.

\section{Архивы}

ИА - Институт Аитературы им. Тараса Шевченко (Украина, Киев).

ГА СБУ - ГосуАарственный архив САужбы безопасности Украины (Украина, Киев).

\section{Литература}

Анциферов, Н.П. (1992). Из дум о бымом: Воспоминания / вступ. ст., сост., прим. и аннот. А.И. Аобкина. Москва: Феникс. 512 с.

Вайнштейн, О.Б. (2005). Аенди: мода, митература, стиль жизни. Москва: НАО. 640 с. Єфремов, С.О. (1997). Щоденники (1923-1929). Киев. 848 с.

Камендарь (1916). Справочная и адресная книга г. Киева. 1916 г. 836 с.

Оберучева, Анна Николаевна (1923-1924). ГА СБУ. № 55435, т. 18. 23 ^.

Полонська-Василенко, Н. (2011). Спогади / упоряА. В. Шевчук. Киев: ВиА. Аім «КиєвоМогилянська академія». $542 \mathrm{c.}$

[б. а.] (1924а). Аекція Білого. 25/II в Пролетарському будинку мистецтв мекція, тема: «ОАна из обителей царства теней». Більшовик. 21 февраля. № 43. С. 6.

[б. а.] (1924b). Аекция Эренбурга (18 февраля). Пролетарскал правда. 16.02. № 39. C. 4 .

[6. а.] (1924c). «Пьяный оператор» (о мекции Эренбурга). Пролетарская правда. 20.02. № 42. C. 3.

13 С. Рейсер перечитывал эти записи 29 Аекабря 1973 года, о чем он записац на помях (ИА, ф. 243, А. 34, ^. 25 об.). 
Рейсер, С.А. (1924, 1926, 1927). Записники С. Рейсера. 1924, 1926, 1927. Notes. ИА. Ф. 243. A. 39. 37 А.

Рейсер, С.А. (1922). Заметки, мысли, конспекты, выписки и пр. ИА. Ф. 243. А. 34.36 м. Рейсер, С.А. (1923, 1926). Записники. 1923, 1926. Miscellanea. ИА. Ф. 243. А. 38. № 1,

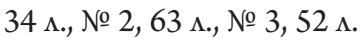

Рейсер, С.А. (1923-1924). Поэтика. Наука о композиции. Отдельные заметки мичного содержания. Тетрадь из конспектов и отдельных заметок. ИА. Ф. 243. А. 26. 111 А.

Рейсер, С.А. (1921). Аекционнал книжка студента. ИА. Ф. 243. А. 41.7 ^.

Рожков, А.Ю. (2016). В кругу сверстников: Жизненный мир молодого человека в Советской России 1920-х годов. Москва: НАО. 2-е изА. 640 с.

Хоффманн, А.А. (2018). Взращивание масс. Модерное государство и советский социализм. 1914-1939; пер. с. англ. А. Терещенко. Москва: НАО. 424 с.

Hellbeck, J. (2009). Revolution in My Mind. Writing a Diary under Stalin. Cambridge, Massachusetts, London, England: Harvard University Press. 436 p.

\section{Filoloǵijas students 20. gadsimta 20. gadu Padomju Ukrainā: Solomona Reisera piezimju burtnīcas}

Rakstā aplūkotas nepublicētas Solomona Reisera piezīmju burtnīcas (19051989), kas glabājas Ukrainas Zinātņu akadēmijas Tarasa Ševčenko Literatūras institūta arhīvā Kijevā. Raksts apliecina, ka šāda rakstura ego dokumenti var kḷūt par svarīgu 20. gadu Kijevas kultūras un literatūras dzīves izpētes avotu. Pamatojoties uz arhīva dokumentiem, identificēta S. Reisera tuvas paziņas, Annas Oberučevas (1891-1982), personība. A. Oberučeva, kulturologa un vēsturnieka Nikolaja Anciferova sievas māsa, piedalijāa vienā no skaḷākajiem PSRS politiskajiem procesiem - Kijevas apgabala Aktivitāšu centra darbībā (1923-1924).

\section{Philology Student in Soviet Ukraine 1920s: Solomon Reiser's notebooks}

This article explores the notebooks of Solomon Abramovich Reiser (1905-1989), which are stored in the Archives of T. Shevchenko Institute of Literature of the National Academy of Sciences of Ukraine in Kiev. The paper shows that ego-documents can become an important source for studying the literary and cultural situation in Kiev in 1920s. The archival documents let identify Reiser's friend, Anna Nikolayevna Oberucheva (1891-1982), who was the sister-in-law of famous historian N. Antsiferov. During 1923-1924 Oberucheva was the defendant in the political process in the USSR - the Kiev Regional Centre for Action (1923-1924). 